\author{
Adam RYBKA ${ }^{1}$ \\ Marta JAŃCZUK ${ }^{2}$ \\ Klaudia JAREMA-KUŚNIERZ ${ }^{3}$ \\ Jaime ROSET CALZADA ${ }^{4}$
}

\title{
KSZTAETOWANIE WYSOKICH OBIEKTÓW ARCHITEKTURY W TKANCE MIEJSKIEJ RZESZOWA
}

\begin{abstract}
Kwestia kształtowania wysokiej architektury w przestrzeni miejskiej jest obecna w architekturze, urbanistyce i naukach społecznych od początku XX wieku do współczesności. Odniesienia do tej idei są widoczne do dziś w praktyce i teorii architektury w projektach budynków oraz w publikacjach. Artykuł omawia temat opisujący ideę kształtowania wysokiej architektury w przestrzeni miejskiej. Dwa przykłady projektów wysokich budynków w Rzeszowie zostały opisane. Próba odpowiedzi na pytanie czy kształtowanie wysokich obiektów architektury w zabudowie miejskiej Rzeszowa jest uzasadnione przestrzennie. Ukazanie kształtowania wysokich obiektów architektury w zabudowie miejskiej Rzeszowa na dwóch przykładach - jako odpowiedź na potrzeby miasta. Poruszenie problemu trwałości konstrukcyjnej i technologicznej, Kształtowania formy obiektu w oparciu o wybrane rozwiązania konstrukcyjne, optymalizację bryłową zastosowanych rozwiązań. Dwa przykłady architektoniczne zależne od miejsca lokalizacji w dwóch różnych miejscach środowiska miejskiego Rzeszowa, stanowią przeciwwagę niestałości powtarzalnych rozwiązań.
\end{abstract}

Słowa kluczowe: architektura obiektów biurowych i hotelowych, formowanie bryły, trwałość konstrukcji, środowisko miejskie, Rzeszów

\footnotetext{
${ }^{1}$ Autor do korespondencji / corresponding author: Adam Rybka, Politechnika Rzeszowska, Zakład Urbanistyki i Architektury, al. Powstańców Warszawy 12, 35-959 Rzeszów, tel. 178651624, akbyr@prz.edu.pl

2 Marta Jańczuk, Politechnika Rzeszowska, al. Powstańców Warszawy 12, $35-959$ Rzeszów, tel. 661182934,martajanczuk@gmail.com

${ }^{3}$ Klaudia Jarema-Kuśnierz, Politechnika Rzeszowska, al. Powstańców Warszawy 12, 35-959 Rzeszów, tel. 664028004, klaudiajarema@ gmail.com

4 Jaime Roset Calzada, Escola Tècnica Superior d'Arquitectura de Barcelona, Diagonal, 649, 08028 Barcelona, Hiszpania, tel. 0034696570 985, jaimros@gmail.com
} 


\section{Wstęp}

Rzeszów znajduje się w grupie dynamicznie rozwijających się polskich miast. Jego atutem jest położenie geograficzne. Miasto jest ważnym punktem na mapie Europy. Tu krzyżują się trakty drogowe: międzynarodowe trasy DreznoKijów oraz drogi krajowe nr 9 i 19, umożliwiające najkorzystniejsze połączenie krajów skandynawskich i nadbałtyckich z państwami Europy SrodkowoWschodniej. Realizowana autostrada A-4 zapewni dogodne połączenie sieci dróg Europy Zachodniej z Ukrainą. Bardzo dużym atutem Rzeszowa jest Międzynarodowy Port Lotniczy Rzeszów Jasionka, dysponujący drugim pod względem długości w Polsce pasem startowym. Rzeszów posiada regularne połączenia lotnicze z znaczącymi miastami europejskimi [4].

Biorąc pod uwagę dynamiczny rozwój Rzeszowa uzasadnione jest projektowanie, na jego obszarze, budynków wysokich. Związane jest to z naturalnym ograniczeniem powierzchni terenów śródmiejskich dostępnych pod zabudowę. Istnieje tutaj zwarta zabudowa, dlatego mamy nie wiele potencjalnej przestrzeni do zagospodarowania. $\mathrm{W}$ związku $\mathrm{z}$ tym względy ekonomiczne $\mathrm{i}$ techniczne zmuszają inwestorów, a wraz z nimi projektantów, do stawiania coraz wyższych obiektów [2]. Dodatkowo grunty miejskie mają wysoką cenę, dlatego inwestorzy preferują wybudowanie wysokiego budynku na niewielkiej działce. Są to czynniki skłaniające do piętrzenia budynków w górę.

Budynki wysokie są projektowane dla dość ograniczonego zakresu funkcji. Ponad $80 \%$ wieżowców to budynki biurowe, kilka procent to hotele i mieszkaniowe. Niekiedy budynki tego typu pełnią funkcje mieszkaniowo-biurowo-hotelowe, rzadko wyłącznie funkcje mieszkaniowe [1].

Budynki wysokościowce podkreślają prestiż miasta i pokazują jego sprawność i atrakcyjność gospodarczą. Taka zabudowa jest często wizytówką miasta. Przyciąga biznesmenów oraz inwestorów pragnących prowadzić swoje interesy w danym mieście.

Krajobraz Rzeszowa kształtował się przez stulecia, rozwijając swoje pewne charakterystyczne cechy. Lokalizacja oraz forma akcentów wieżowych i wysokościowych, widocznych w sylwecie miasta wynikała ze specyficznych zasad kodu kształtowania przestrzeni. Współczesne budynki wysokościowe mają inny charakter, odmienną funkcję i formę, a także odmienne są zasady ich lokalizacji w strukturze miasta. Wpływ budynków wysokościowych wiąże się z ich dużym zasięgiem oddziaływania wizualnego $\mathrm{w}$ sylwecie miasta. Jest to szczególnie istotne $\mathrm{w}$ odniesieniu do wartościowych widoków miasta, które powinny być chronione $\mathrm{z}$ uwagi na swoje walory kulturowe i historyczne.

Od kilku lat toczy się dyskusja na temat wysokości zabudowy w Rzeszowie. Jedni uważają, że w Rzeszowie wieżowce są niepotrzebne i historycznie nieuzasadnione, inni widzą w nich symbol nowoczesności i metodę optymalizacji zagospodarowania przestrzeni miejskiej. 
Budynki wysokościowe są wyróżnikiem nowoczesnej gospodarki. Powinny powstawać pod warunkiem, że nie naruszają ładu przestrzennego w mieście i tworzą przemyślaną kompozycję. Ostatnie lata przyniosły silną tendencję realizacji w Rzeszowie budynków wysokościowych. Niektóre propozycje są bardzo interesujące. Aby jednak dobrze spełniły swoją rolę potrzebne są szczegółowe studia i analizy architektoniczne i urbanistyczne wizerunku śródmieścia Rzeszowa [3].

Formy budynków wysokich stają się coraz bardziej skomplikowane przestrzennie, zaskakują urodą i elegancją. Współczesnej technologii takich budynków towarzyszy nurt działań proekologicznych oraz idea budynku inteligentnego. Wieżowce są źródłem postępu w dziedzinie techniki i technologii budowlanej. Wyższa klasa rozwiązań instalacyjnych, mechanicznych, przeciwpożarowych, większa szczelność i wytrzymałość ścian osłonowych powoduje, iż mogą one być, po modyfikacji, stosowane w zabudowie niższych budynków. Organizacja działania wieżowca, bezpieczeństwo wielu set czy tysięcy przebywających w nim ludzi, niezawodność rozwiązań technicznych sprawiają, iż nazwa „budynek inteligentny" jest najczęściej kojarzony z obiektami wysokimi [1].

Budynki wysokie tworzą nowy ,drugi poziom” miasta, wzbogacają formę jego przestrzeni, zaskakują wydobytą przez światło sztuczne geometrią w nocy.

Struktura konstrukcyjna budynku wysokościowego powinna zapewniać bezpieczeństwo budynku oraz jego otoczenia. Oznacza to odpowiednią: stateczność, sztywność przestrzenną, wytrzymałość elementów i złączy, także trwałość oraz bezpieczeństwo pożarowe i sejsmiczne. Konstrukcja powinna równocześnie spełniać wymagania architektoniczne dotyczące szczególnie mobilności funkcji, dostępności komunikacji oraz łatwości transmisji przewodów instalacyjnych [1].

Przyjęta konstrukcja budynku jest istotnym czynnikiem kształtowania jego wyrazu architektonicznego. Architekt nie może dowolnie formować bryły takiego budynku. Zmuszony jest, w pewnym stopniu, podporządkować ją wymogom konstrukcyjnym. Duże ingerencje i modyfikacje w kształcie bryły na wyższych kondygnacjach mogą zagrażać stateczności budynku. Projektant musi uwzględniać te uwarunkowania i czynniki przy kształtowaniu wrażenia estetycznego bryły budynku. Wpływ na wygląd budynku oprócz konstrukcji ma również funkcja, lokalizacja oraz charakterystyka otaczającego terenu.

Problematyka projektowania budynków wysokich została przedstawiona poniżej na przykładach dwóch projektów budynków użyteczności publicznej:

- wysokiego budynku hotelowego (2) - praca dyplomowa autorstwa mgr inż. arch. Klaudii Jaremy-Kuśnierz. Promotor pracy dr hab. inż. arch. Adam Rybka, prof. PRz.

- wysokiego budynku biurowego (3) - praca dyplomowa autorstwa mgr inż. arch. Marty Jańczuk. Promotor pracy dr hab. inż. arch. Adam Rybka, prof. PRz. 


\section{Wysoki budynek hotelowy}

\subsection{Lokalizacja}

Projektowany budynek zlokalizowany jest w Rzeszowie, w jego północnej części na działkach numer 55, 57/1, 57/2, 558/1, 58/2, 58/359, 61,62/3, 63/1, 68/45. Działki znajdują się pomiędzy trzema ulicami: Warszawską, Aleją Wyzwolenia, Kornela Ujejskiego (rys. 1).

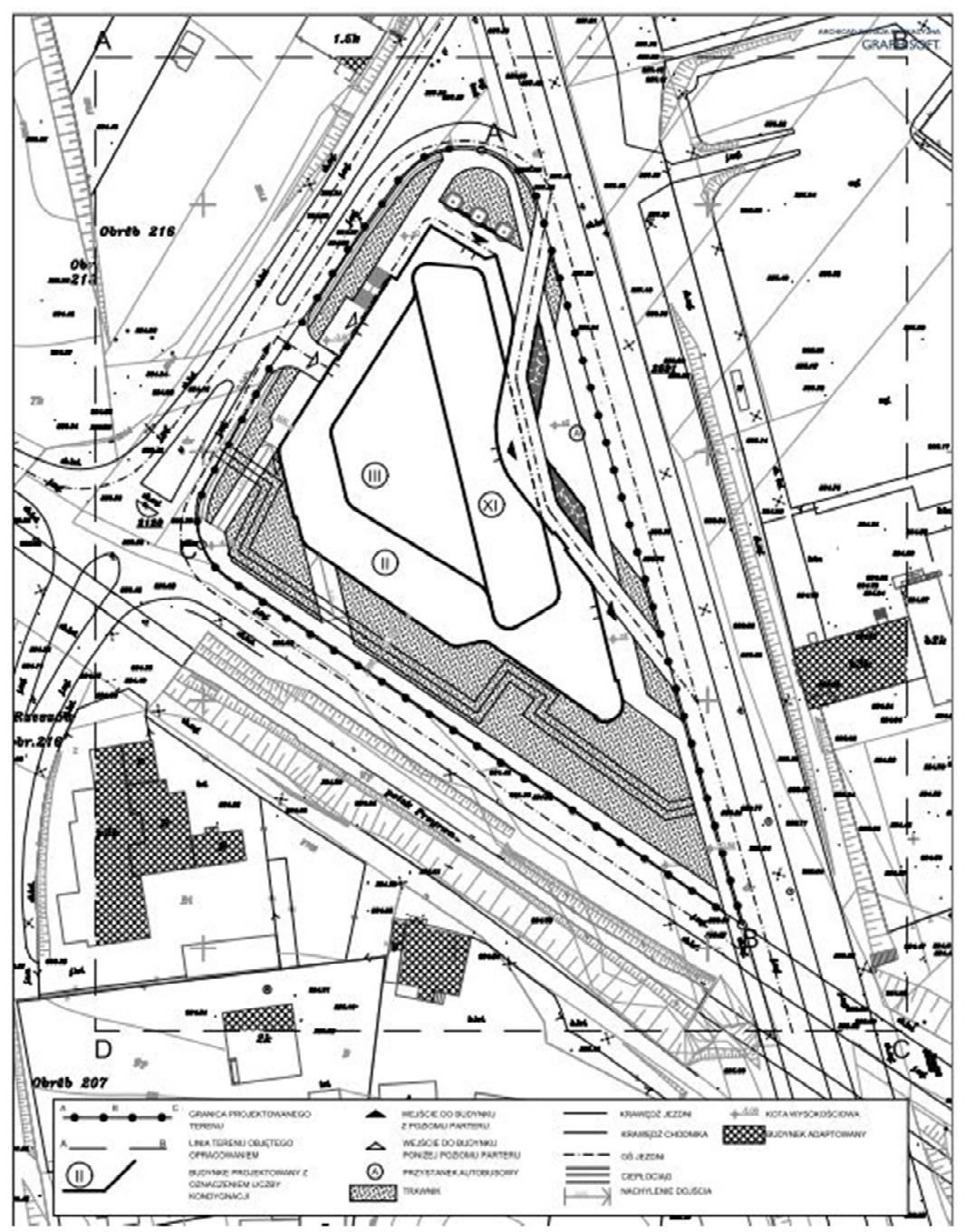

Rys. 1. Projekt zagospodarowania terenu. Fragment pracy dyplomowej Klaudii Jaremy-Kuśnierz - Projekt architektoniczny wysokiego budynku hotelowego

Fig. 1. Land development plan. Fragment of Klaudia Jarema-Kusnierz diploma thesis - Architectural project of a high hotel building 
Podczas wyboru lokalizacji architekt kierował się potrzebami osób przyjeżdżających do miasta. Najwięcej ludzi podróżuje samochodami lub samolotami. Proponowana lokalizacja obiektu jest bardzo sprzyjająca dla funkcjonowania hotelu. Projektowany budynek znajduje się przy trasie łączącej miasto z autostradą A4. Ulica Warszawska to droga biegnąca do Portu Lotniczego Jasionka. Dzięki tej lokalizacji obiektu hotelowego osoby zaraz po zjechaniu z A4 lub wylądowaniu na lotnisku, mogą znaleźć miejsce do odpoczynku. Hotel znajduje się na obrzeżach miasta, ale w nie dużej odległości od centrum, co jest również udogodnieniem dla przybyłych osób oraz atutem wybranej lokalizacji.

\subsection{Kształtowanie bryły}

Najbardziej interesujące są projekty architektoniczne, w których projektant subtelnie i delikatnie ingeruje w formę architektoniczną przez co unika błędu w jej kształtowaniu. Jak ogólnie wiadomo, nie można zaprojektować budynku, którego forma, wygląd zewnętrzny zostanie pozytywnie oceniony przez wszystkich obserwatorów, ponieważ odbiór obrazu, rzeźby, sztuki czy ogólnie formy jest zawsze subiektywny. Ważniejsze od zastosowanego warsztatu architektonicznego - podstawowego narzędzia architektury, jest zrozumienie kontekstu przestrzennego danego obiektu. Szczerość formy, odporność na zmieniające się gusty i trendy, prestiż, wpływ na emocje obserwatora to główne czynniki wpływające na percepcję obiektu architektonicznego. Percepcja determinuje odbiór architektury tak mocno jak jej początek czyli wstępna idea-design. Dużym wyznacznikiem projektowania bryły omawianego obiektu była jego lokalizacja oraz teren. Jednym z problemów tworzenia obiektu był trójkątny kształt działki. Narzucał on obrys budynku. Niewielka powierzchnia działki ograniczała poziome gabaryty budynku.

Budynek został zróżnicowany pod względem wysokości, posiada główny 11 kondygnacyjny środkowy fragment oraz stopniowanie ilości kondygnacji, niższych bocznych części.

Niższe, rozłożyste części budynku spełniają funkcje usługowo-rekreacyjną. Pomimo trójkątnego planu budynek posiada on prostokątny ryzalit główny, w którym dłuższy bok jest równoległy do ul. Warszawskiej podkreślając jej miejski charakter. Dwie dłuższe ściany są orientowane w kierunkach wschódzachód, co jest korzystne przy projektowaniu hotelowych jednostek mieszkaniowych. Podsumowując głównymi wyznacznikami w tworzeniu bryły budynku był kształt działki, sąsiednie drogi, orientacja względem stron świata oraz funkcja podstawowa (rys. 2). 


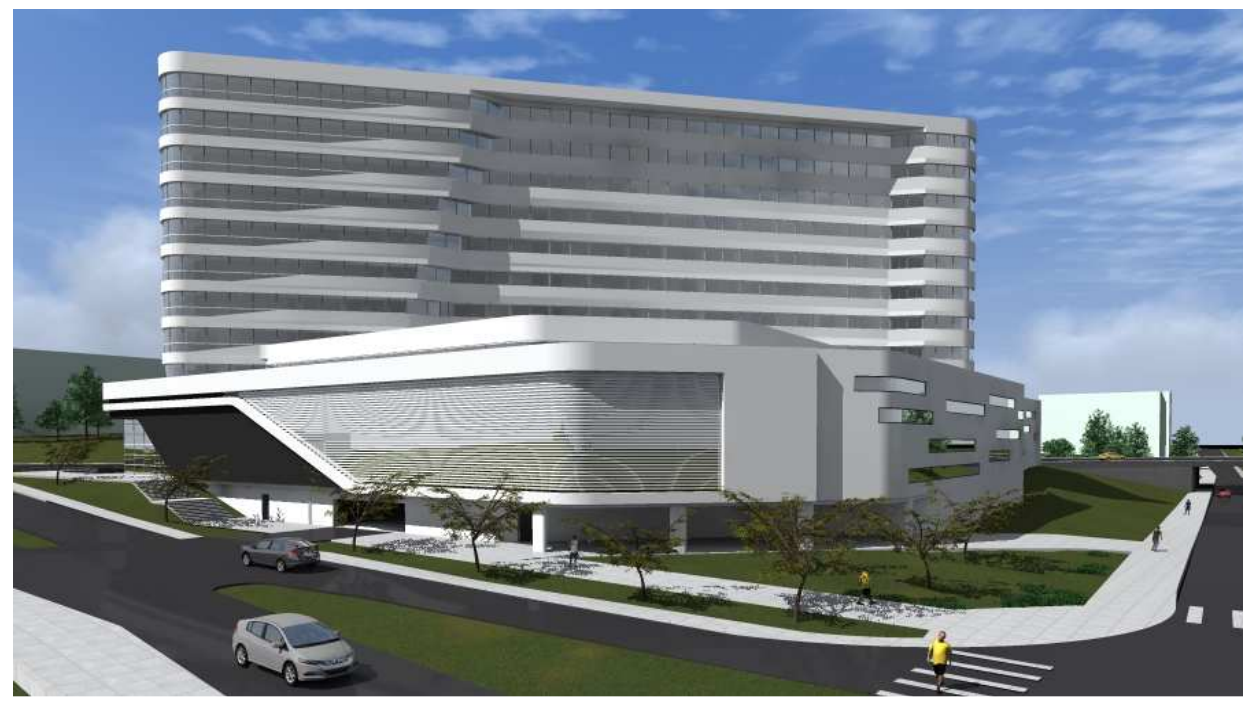

Rys. 2. Wizualizacja. Fragment pracy dyplomowej Klaudii Jaremy-Kuśnierz - Projekt architektoniczny wysokiego budynku hotelowego

Fig. 2. Visualisation. Fragment of Klaudia Jarema-Kusnierz diploma thesis - Architectural project of a high hotel building

\subsection{Funkcja budynku}

Tu pojawia się pytanie dotyczące relacji między formą i funkcją. W tradycyjnym modernistycznym rozumieniu mamy następującą relację: funkcja budynku jest programowym rozwinięciem celu jakiemu ma służyć obiekt. Funkcja jest istotnym czynnikiem wpływającym na kształt i wygląd budynku.

Możliwe jest jednak inne spojrzenie, które zwraca uwagę na to, że funkcja jest do pewnego stopnia nieukształtowaną formą. Formą, która jest przed i ponad funkcją, a na samym początku projektowania znajduje się idea-design. Konkretne, szczegółowe pełne detali myślenie na poziomie design zbytnio materializuje projekt sprowadzając go do pewnej formy lub funkcji. Forma i funkcja powinny być wynikiem modelowania nieskrępowanej idei, a nie wynikiem wynikającym z wcześniej przyjętych założeń bo wtedy nie będzie spójna z pozostałymi czynnikami kształtującymi architekturę.

W projektowanym obiekcie na pierwszej i drugiej kondygnacji nadziemnej o najbardziej rozbudowanym kształcie znajduje się funkcja usługowo-rekreacyjna. W jej skład wchodzą pomieszczenia przeznaczone na restaurację i zaplecze konferencyjne oraz Wellnes\&Spa z dwoma basenami i gabinetami odnowy biologicznej, typu fitness (rys. 3, 4). 


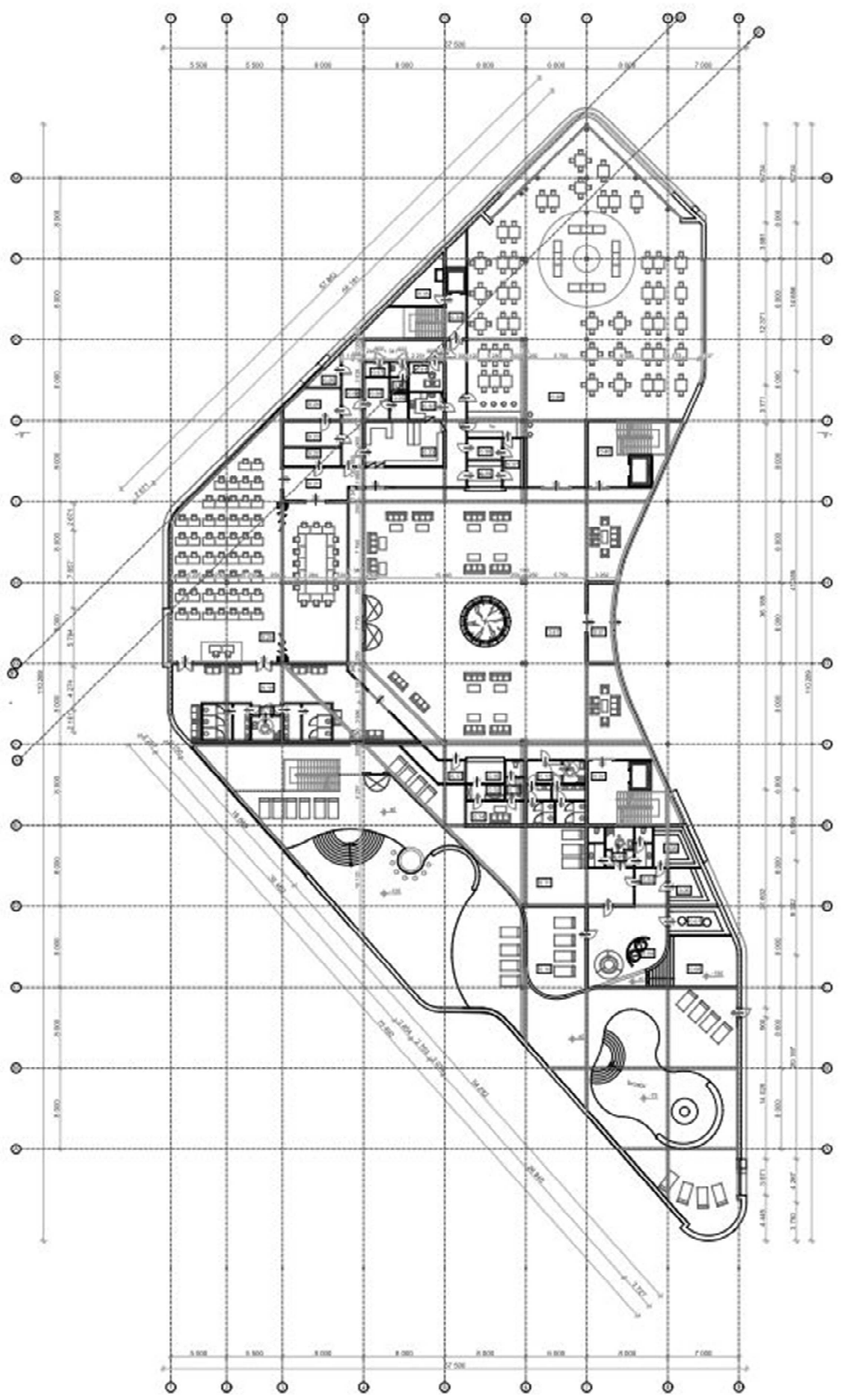

Rys. 3. Rzut kondygnacji I. Fragment pracy dyplomowej Klaudii JaremyKuśnierz - Projekt architektoniczny wysokiego budynku hotelowego

Fig. 3. First floor view. Fragment of Klaudia Jarema-Kusnierz diploma thesis - Architectural project of a high hotel building 


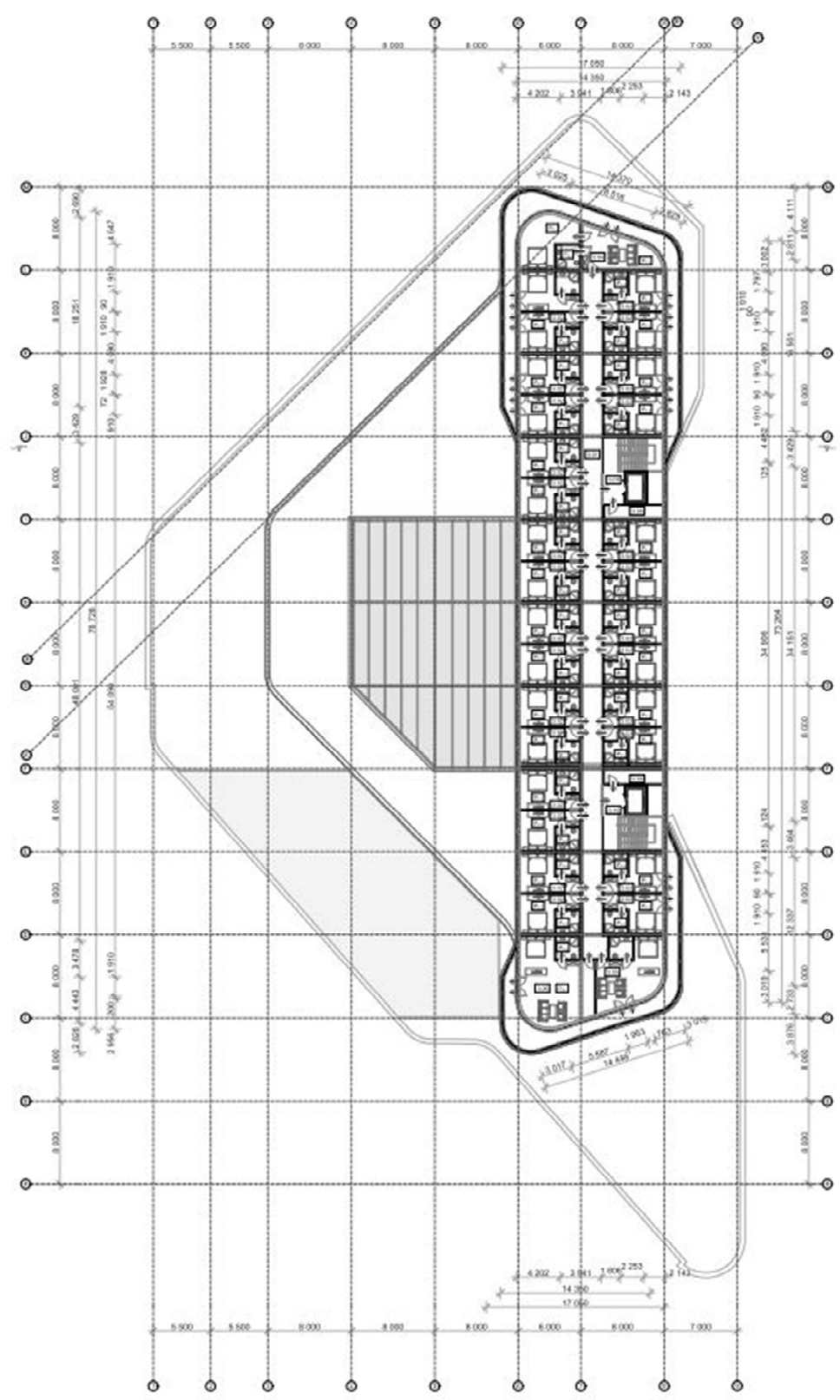

Rys. 4. Rzut kondygnacji III-XI. Fragment pracy dyplomowej Klaudii Jaremy-Kuśnierz - Projekt architektoniczny wysokiego budynku hotelowego

Fig. 4. Floor plan view (third to eleven). Fragment of Klaudia Jarema-Kusnierz diploma thesis - Architectural project of a high hotel building 
Kondygnacja trzecia o mniejszym obrysie przeznaczona jest pod jednostki mieszkaniowe o podwyższonym standardzie użytkowania. Znajdują się tu apartamenty z pokojami kąpielowymi.

Kondygnacje kształtujące najwyższą część budynku posiadają powtarzalna funkcję. Na nich zaprojektowano jednostki mieszkaniowe o podstawowym standardzie. Niektóre z nich posiadają dostęp do ogrodów zimowych, które odgrywają rolę w kształtowaniu elewacji. Budynek dysponuje łącznie 283 pokojami hotelowymi.

\subsection{Konstrukcja}

Budynek hotelowy zaprojektowano jako szkieletowy-żelbetowy. Obiekt składa się z wielokondygnacyjnego układu słupów, rozmieszczonych na siatce wprowadzającej podział rzutu na 8 traktów poprzecznych oraz 12 podłużnych. Słupy zaprojektowano jako żelbetowe o przekroju 30 x $30 \mathrm{~cm}$. Na nich oparte są stropy za pośrednictwem poziomego rusztu złożonego z podciągów. Usztywnienie budynku wykonywane jest ze stężeń umieszczanych w płaszczyźnie ścian zewnętrznych, sztywnych stropów i rdzenia (trzonu) budynku. Wewnątrz tej konstrukcji umieszczone są żelbetowe klatki schodowe (zaproponowano jako dwubiegowe) oraz szyby windowe.

W budynku zaprojektowano żelbetowe ławy fundamentowe stanowiące oparcie dla słupów i ścian nośnych. Wysokość ławy $-40 \mathrm{~cm}$, szerokość $-70 \mathrm{~cm}$.

Ściany zewnętrzne stanowią wypełnienie szkieletu całej konstrukcji. Wykonane z pustaków ceramicznych na zaprawie cementowo-wapiennej. Ich grubość wynosi $29 \mathrm{~cm}$. Dodatkowo na ścianach zewnętrznych zaprojektowano ocieplenie w postaci wełny mineralnej grubości $15 \mathrm{~cm}$.

Zaprojektowano przerwy dylatacyjne, które dzielą budynek na cztery część. Wydzielają one wszystkie elementy konstrukcyjne w jednym przekroju od fundamentów po dach. Części te samodzielnie przenoszą przewidywane obciążenia, odkształcenia i przesunięcia.

W budynku zaprojektowano dach jako stropodach pełny na stropie żelbetonowym, jego nachylenie wynosi 3\%. Składa się on z żelbetowej płyty stropowej grubości $15 \mathrm{~cm}$, warstwy spadkowej z betonu, foli paroizolacyjnej, wełny mineralnej w układzie dwuwarstwowym oraz pokrycia dachowego $\mathrm{z}$ dwóch warstw papy termozgrzewalnej.

Wysokość kondygnacji parteru oraz pierwszego piętra wynosi 4,0 m, podziemnej 3,1 m, natomiast pozostałych przeznaczonych pod jednostki mieszkaniowe 3,3 m. Maksymalna wysokość budynku wynosi 38,40 m.

\section{Wysoki budynek biurowy}

\subsection{Lokalizacja}

Teren na, którym został zaprojektowany budynek biurowy składa się z czterech działek o numerach 662, 661/4, 1812/1, 1812/3 (rys. 5). Powierzchnia terenu wynosi 300,0574 ar (ok. 3,0 hektary). Działki sąsiadują od strony wschodniej 


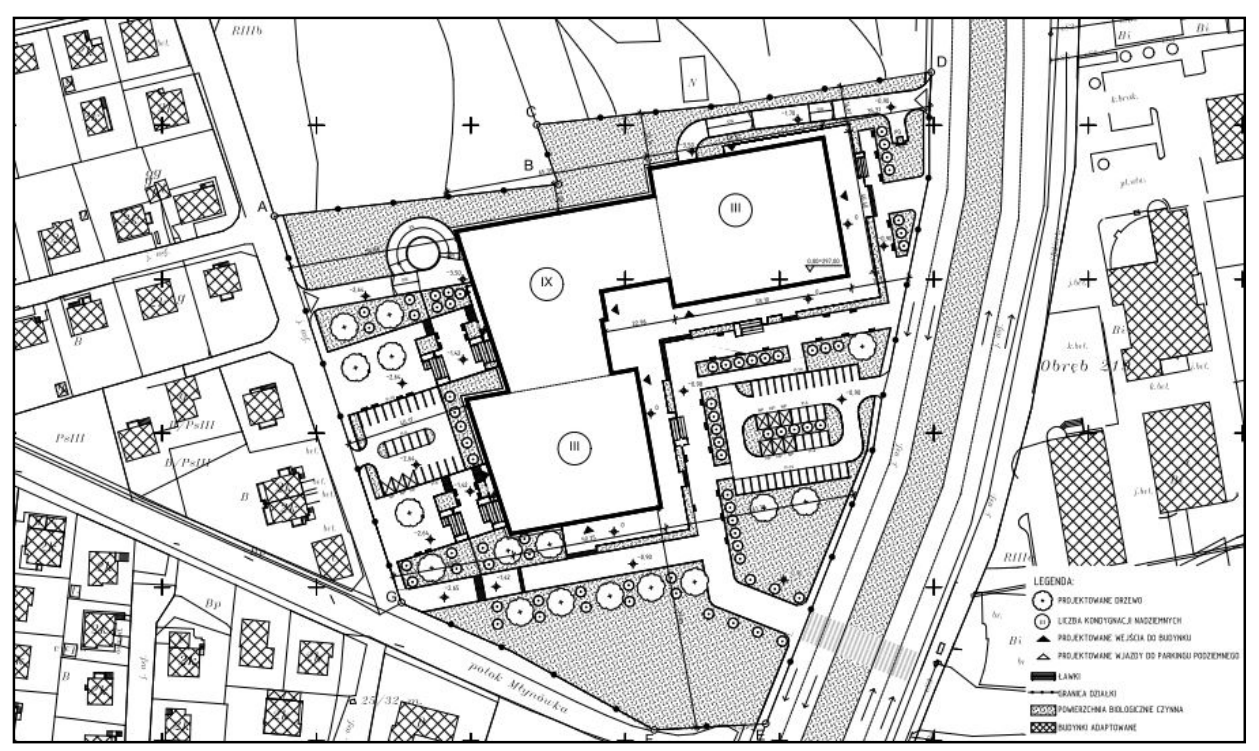

Rys. 5. Projekt zagospodarowania terenu. Fragment pracy dyplomowej Marty Jańczuk - Projekt architektoniczny wysokiego budynku biurowego

Fig. 5. Land development plan. Fragment of Marta Jańczuk diploma thesis - Architectonic project of the high office building

z drogą krajową (ul. Armii Krajowej), od zachodniej z ul. Lotników, a od strony południowej graniczy z potokiem Młynówka. Sąsiedztwo ulic i dróg w obrębie działek stwarza dobre warunki komunikacyjne dotyczące połączeń. Projektowany biurowiec usytuowany jest w sąsiedztwie dużych znaczących obiektów handlowo-usługowych takich jak: Skarbiec Narodowego Banku Polskiego, sklep Makro. Budynek rozmyślnie zaprojektowany został na linii widokowej prowadzącej od Zamku Lubomirskich (obecnie siedziba Sądu Okręgowego) przez Capital Tower, Millenium Hall, Capital Park. Funkcja biurowa jest uzasadniona ze względu na brak takich rozwiązań w śródmiejskiej części Rzeszowa. Jako budynek o nowoczesnej technologii stworzy komfortowe warunki pracy i przyczyni się do wzrostu liczby miejsc pracy w mieście, co jest bardzo ważne w tym regionie. Dodatkowym atutem jest napływ przyszłych klientów, interesantów i inwestorów. Nowoczesne budynki biurowe poprawiają krajobraz i wizerunek miasta. Budynek został zaprojektowany na linii widokowej, która wyznaczona jest przez ważne obiekty dla miasta Rzeszowa. Są nimi: Zamek Lubomirskich (obecnie siedziba Sądu Okręgowego), Capital Towers, Millenium Hall, Wyższa Szkoła Prawa i Administracji przy cegielnianej 14, Biblioteka Uniwersytetu Rzeszowskiego, Centrum Dydaktyczno-Naukowe Mikroelektroniki i Nanotechnologii jak również Capital Park. Patrząc w kierunku północnym możemy zauważyć w oddali Sąd Rejonowy na Kustronia 4, a w dalszym zasięgu Galeria Rzeszów z Hotelem Rzeszów. Dzięki temu obiekt wpasowuje się w krajobraz 
urbanistyczny, jest zaznaczony w zauważalny sposób dla miasta, nie dominuje nad miastem, natomiast wyznacza określony kierunek. Zaprojektowany w tym miejscu jest punktem zwrotnym, pomocnym przy orientacji przestrzennej w Rzeszowie (rys. 6).

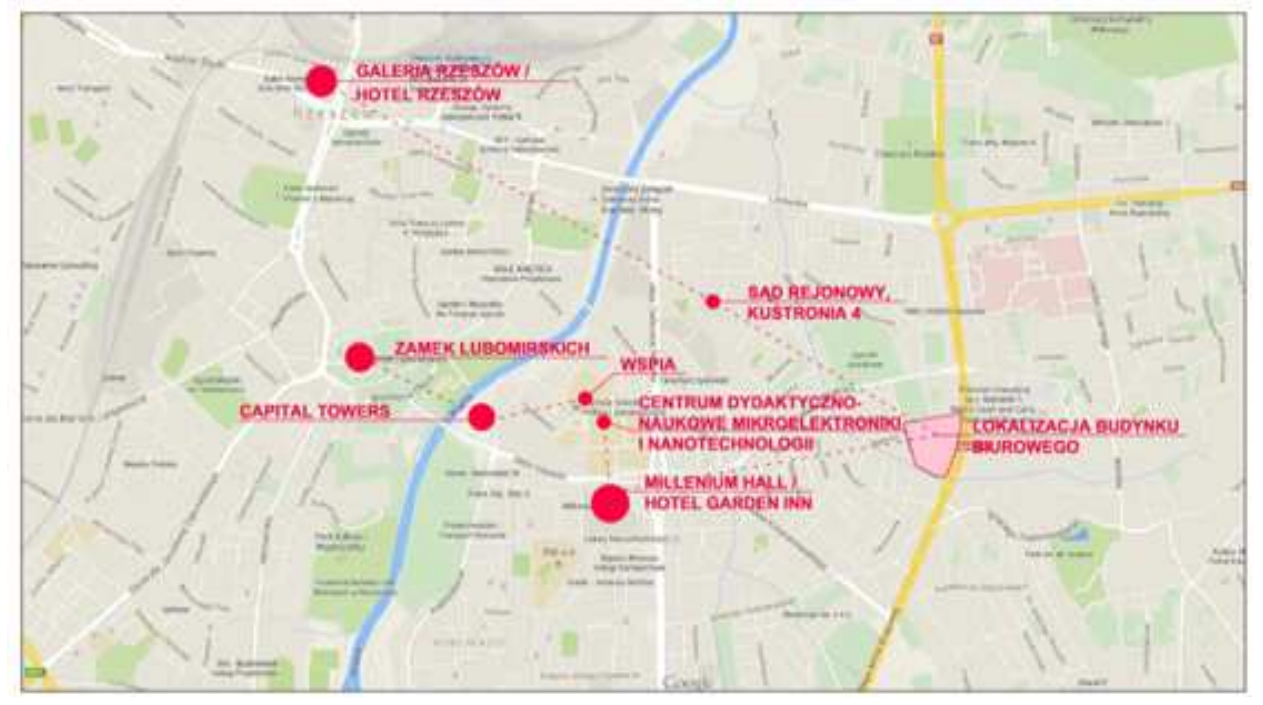

Rys. 6. Lokalizacji budynku biurowego - schemat ilustrujący zasięg widoku

Fig. 6. Office building location - a diagram showing the view range

Zaprojektowany budynek ma zróżnicowane wysokości. W dwóch częściach jest trzykondygnacyjny, a jego centralny trzon posiada IX kondygnacji nadziemnych. Główne wejścia znajdują się od strony: południowo-wschodniej, wschodniej i południowej. Natomiast wjazdy na parking podziemny przewidziano od strony zachodniej i wschodniej. Oprócz wejść głównych do budynku zaprojektowano jeszcze pięć innych wejść. Ze względu na ukształtowanie terenu działki, zaprojektowano schody terenowe oraz pochylnie spełniające wymogi dla osób niepełnosprawnych.

Na działce zaprojektowano place rekreacyjno-wypoczynkowe z ławeczkami i zagospodarowaną zielenią. Od strony ul. Armii Krajowej i Lotników zaprojektowano parkingi naziemne wraz z miejscami postojowymi dla osób niepełnosprawnych.

\subsection{Kształtowanie bryły}

Podczas kształtowania bryły brano pod uwagę kierunki istniejącej zabudowy, których efektem jest kształt projektowanego budynku wysokiego. Czerwone linie ukazują kierunki istniejącej zabudowy po stronie wschodniej, do której nawiązano w projektowanym obiekcie. Od strony zachodniej linia zabudowy 
projektowanego obiektu nawiązuje do drogi. $\mathrm{Z}$ kolei niebieskie linie odnoszą się do kierunku oraz zabudowy po stronie północnej działki (rys. 7).

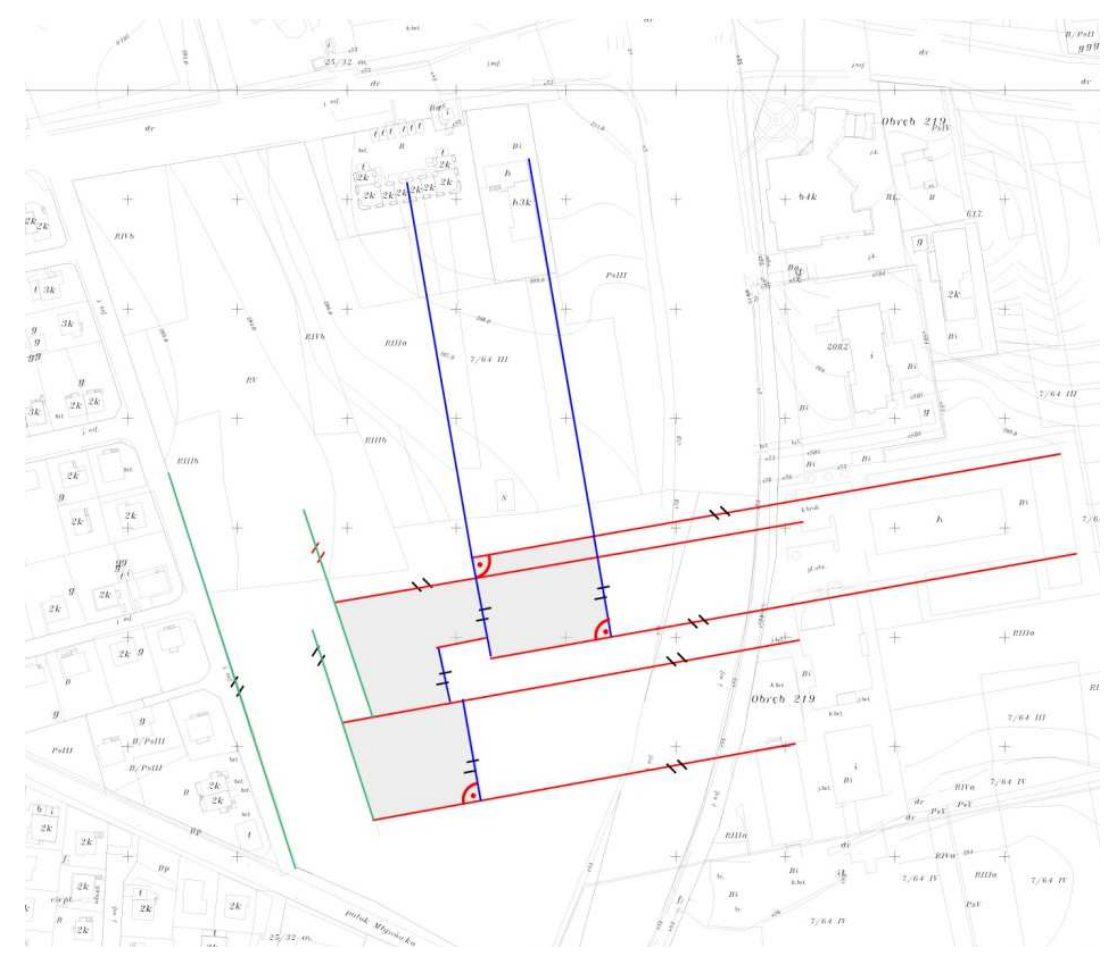

Rys. 7. Kierunki projektowe. Fragment pracy dyplomowej Marty Jańczuk - Projekt architektoniczny wysokiego budynku biurowego

Fig. 7. Design directions. Fragment of Marta Jańczuk diploma thesis - Architectonic project of the high office building

W pierwszej fazie powstała koncepcja zmierzająca do dopasowania obiektu pod względem wysokościowym do otaczającej przestrzeni urbanistycznej, w której dominują budynki w zabudowie niższej (budynki 3-4 kondygnacyjne i jednorodzinne). W sąsiedztwie działki, na której zaprojektowano biurowiec wznosi się wysoki 13 kondygnacyjny budynek. Architekt mając na uwadze wszystkie aspekty uwarunkowania przestrzennego, zaprojektował 9 kondygnacyjny, główny trzon budynku oraz dwie części niższe 3 kondygnacyjne. Ta idea doprowadziła do zaprojektowania budynku o zróżnicowanej wysokości. Bryła budynku urozmaicona została zastosowanym materiałem. W głównej najwyższej części 9 kondygnacyjnej zastosowano duże powierzchnie przeszklone. Przeszklono również pasaże znajdujące się w niższej części obiektu, które dodatkowo łączą bryłę w jedną całość. W dwóch częściach niższych zastosowano pio- 
nowy podział okien nawiązujący do podziału powierzchni szklanych najwyższej części budynku (rys. 8).

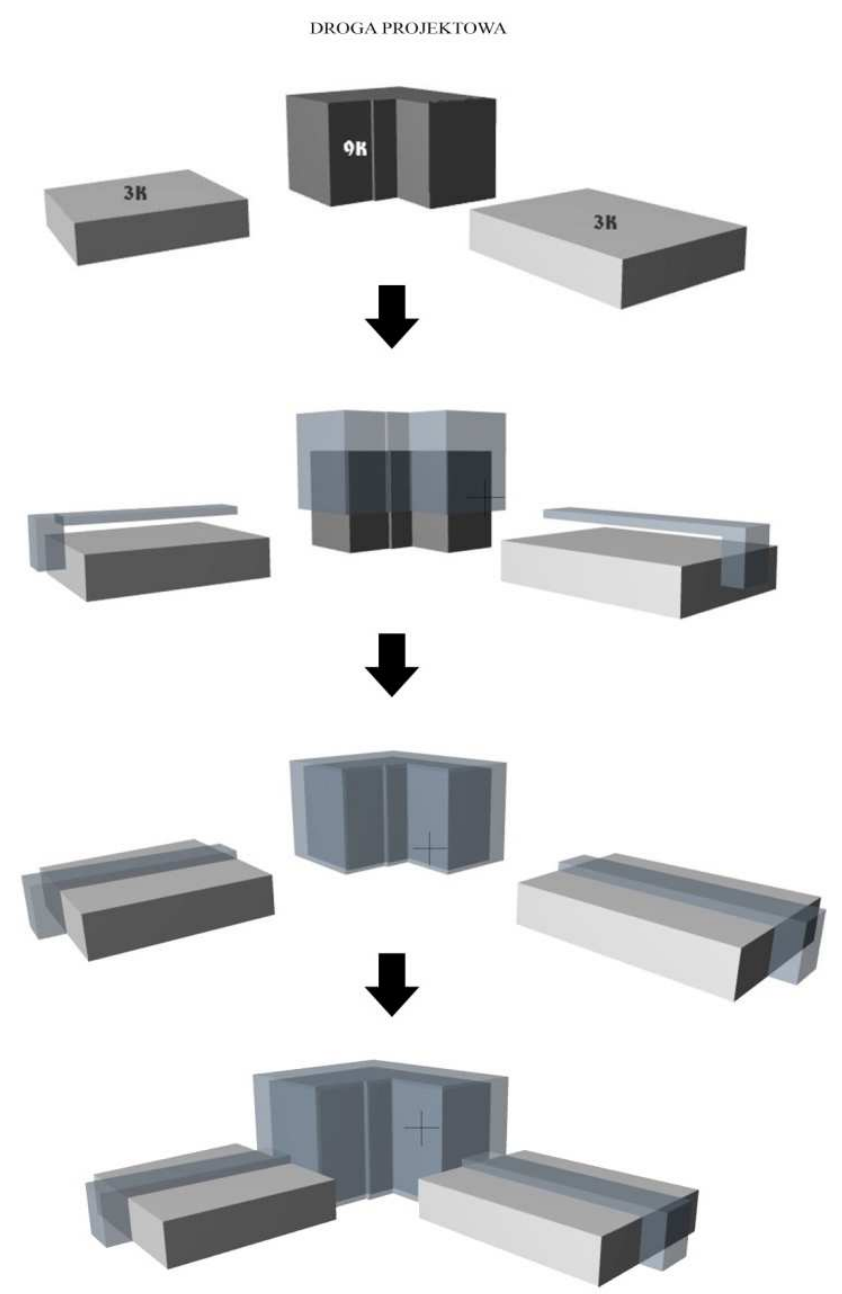

Rys. 8. Fazy powstania bryły. Fragment pracy dyplomowej Marty Jańczuk - Projekt architektoniczny wysokiego budynku biurowego

Fig. 8. Phase of the formation building block. Fragment of Marta Jańczuk diploma thesis - Architectonic project of the high office building

Podsumowując głównymi czynnikami biorącymi udział w kształtowaniu bryły były linie zabudowy sąsiedniej, jej wysokości, funkcja oraz usytuowanie obiektu względem drogi (rys. 9, 10). 


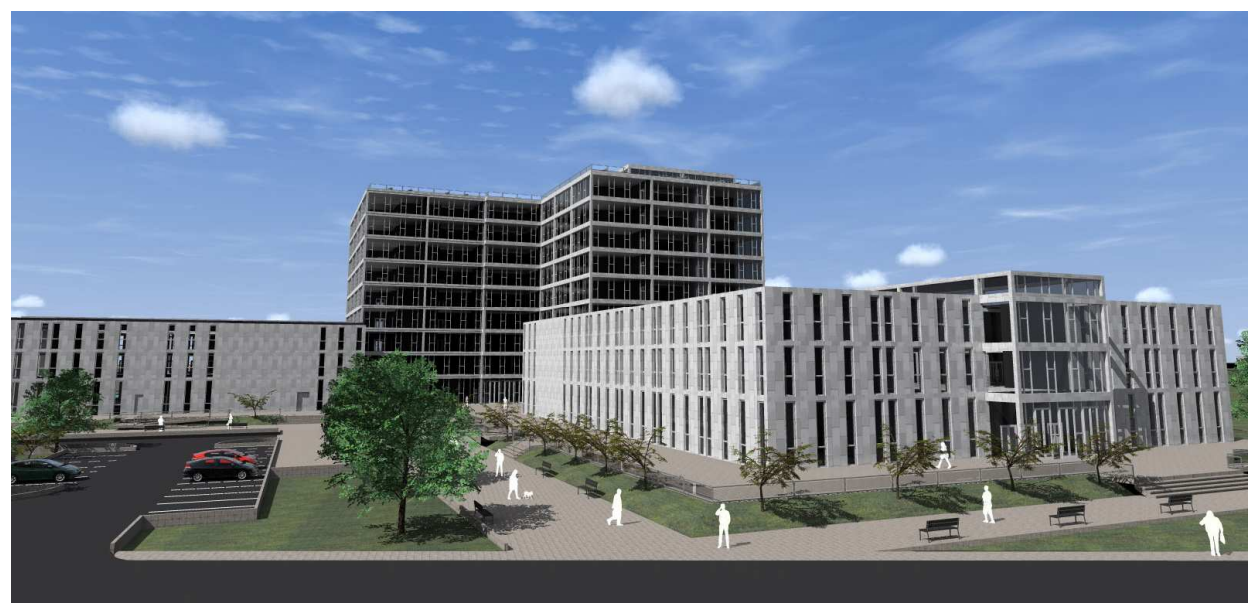

Rys. 9. Wizualizacja. Fragment pracy dyplomowej Marty Jańczuk - Projekt architektoniczny wysokiego budynku biurowego

Fig. 9. Visualisation. Fragment of Marta Jańczuk diploma thesis - Architectonic project of the high office building

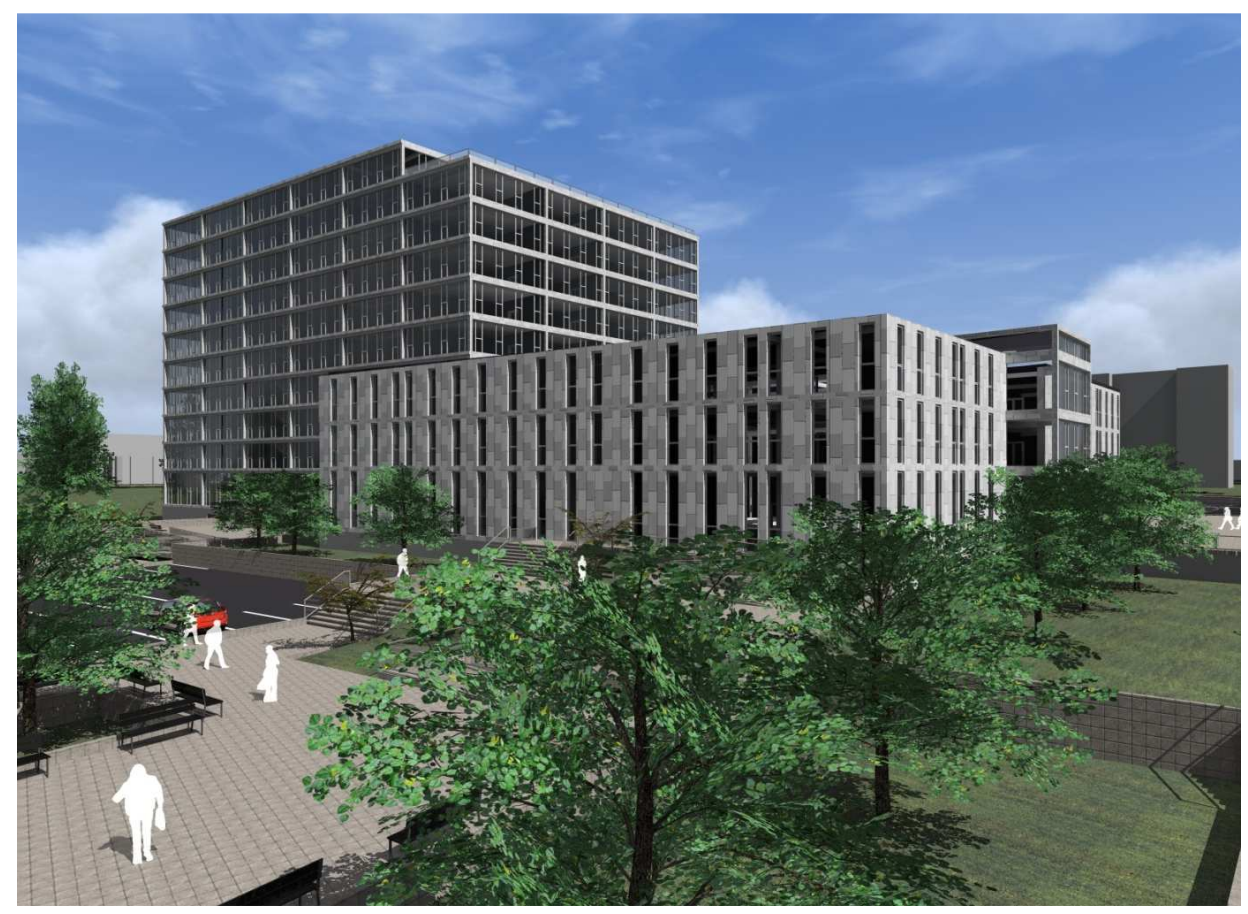

Rys. 10. Wizualizacja. Fragment pracy dyplomowej Marty Jańczuk - Projekt architektoniczny wysokiego budynku biurowego

Fig. 10. Visualisation. Fragment of Marta Jańczuk diploma thesis - Architectonic project of the high office building 


\subsection{Funkcja budynku}

Zaprojektowany budynek jest obiektem wysokim wielokondygnacyjnym wraz z dwoma podziemnymi kondygnacjami parkingowymi i jest przystosowany dla osób niepełnosprawnych. Oprócz głównej funkcji biurowej budynek posiada funkcję: usługową, kulturalno-rozrywkową i naukowo-dydaktyczną. W dwóch kondygnacjach podziemnych znajduje się zaplecze techniczne, w skład którego wchodzi: przyłącz wody, węzeł C.O., rozdzielnia elektryczna, serwerownia, wentylatornia, magazyny oraz powierzchnia parkingowa dla 316 miejsc postojowych, w tym również przeznaczonych dla osób niepełnosprawnych. Bryła budynku składa się z trzech części, które oddzielone są od siebie przerwami dylatacyjnymi.

Dwie niższe części budynku zawierają trzy kondygnacje nadziemne, w których główny hall oraz foyer został dobrze doświetlone poprzez zaprojektowane świetliki dachowe. Kondygnacje skomunikowane są przez zaprojektowane schody ruchome.

Część budynku od strony północno-wschodniej składająca się z trzech kondygnacji nadziemnych w parterze mieści restaurację, dwupiętrowe kasyno, kawiarnię, lokale usługowe pod wynajem, pomieszczenia porządkowe i techniczne oraz sanitariaty. Na I piętrze zaprojektowano lokale usługowe do wynajęcia. III kondygnacja jako część kulturalno-rozrywkowa, gdzie znajdują się szkoła tańca i klub fitness.

Trzecia część od strony południowej również składa się z trzech kondygnacji nadziemnych. W tej części na parterze zaprojektowano restauracje, kawiarnie oraz ekskluzywne lokale usługowe. Na powyższych dwóch kondygnacjach mieszczą się duże sale wykładowe w tym jedna o układzie kinowym, sale konferencyjne o zróżnicowaniu powierzchniowym i układowym.

Trzy pierwsze kondygnacje nadziemne tworzą niższą część obiektu, natomiast wyższe kondygnacje są powtarzalne, tworzą one główny trzon. Centralna część budynku - biurowa, zawiera dziewięć kondygnacji nadziemnych. Łączna powierzchnia biurowa wynosi $9442,72 \mathrm{~m}^{2}$. Biura występujące w obiekcie mają charakter mieszany ponieważ stosuje się wielko powierzchniowe pomieszczenia biurowe typu ,open space”, a także indywidualne mniejsze pomieszczenia biurowe na 4-6 stanowisk. W tej części tj. od strony południowo-wschodniej znajduje się główne wejście do budynku z reprezentacyjnym hallem recepcyjnym, który prowadzi do foyer ekspozycji tymczasowej i galerii sztuki. Na każdej kondygnacji w trzonie głównym oprócz biur zaprojektowano barki kawowe oraz sanitariaty. Część biurowa łączy się komunikacyjne z dwoma pozostałymi częściami budynku. Na ostatniej IX kondygnacji tej części budynku zaprojektowany został taras zielony widokowy, który umożliwia wyjście z biur.

Taki układ bryły budynku uwidacznia zróżnicowanie obiektu i generuje podział funkcji. Komunikację pionową budynku stanowią schody i windy. W budynku zaprojektowano sześć klatek schodowych ewakuacyjnych, z czego dwie 
mieszczą się w głównym trzonie i komunikują dziewięć kondygnacji nadziemnych i dwie kondygnacje podziemne. Do każdej części budynku znajdują się osobne wejścia, jest ich w sumie osiem (rys. 11, 12).

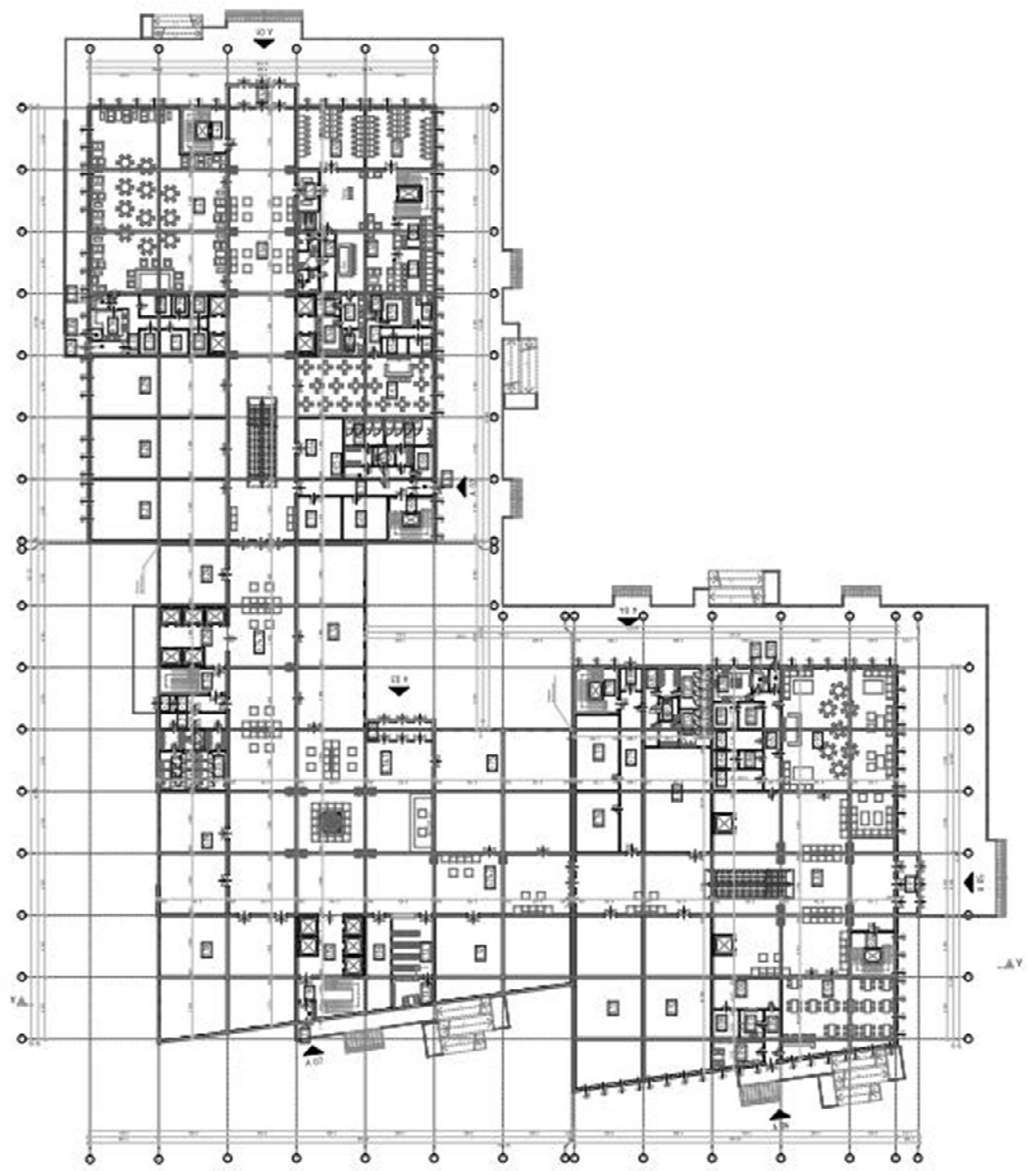

Rys. 11. Rzut kondygnacji I. Fragment pracy dyplomowej Marty Jańczuk - Projekt architektoniczny wysokiego budynku biurowego

Fig. 11. First floor view. Fragment of Marta Jańczuk diploma thesis - Architectonic project of the high office building 


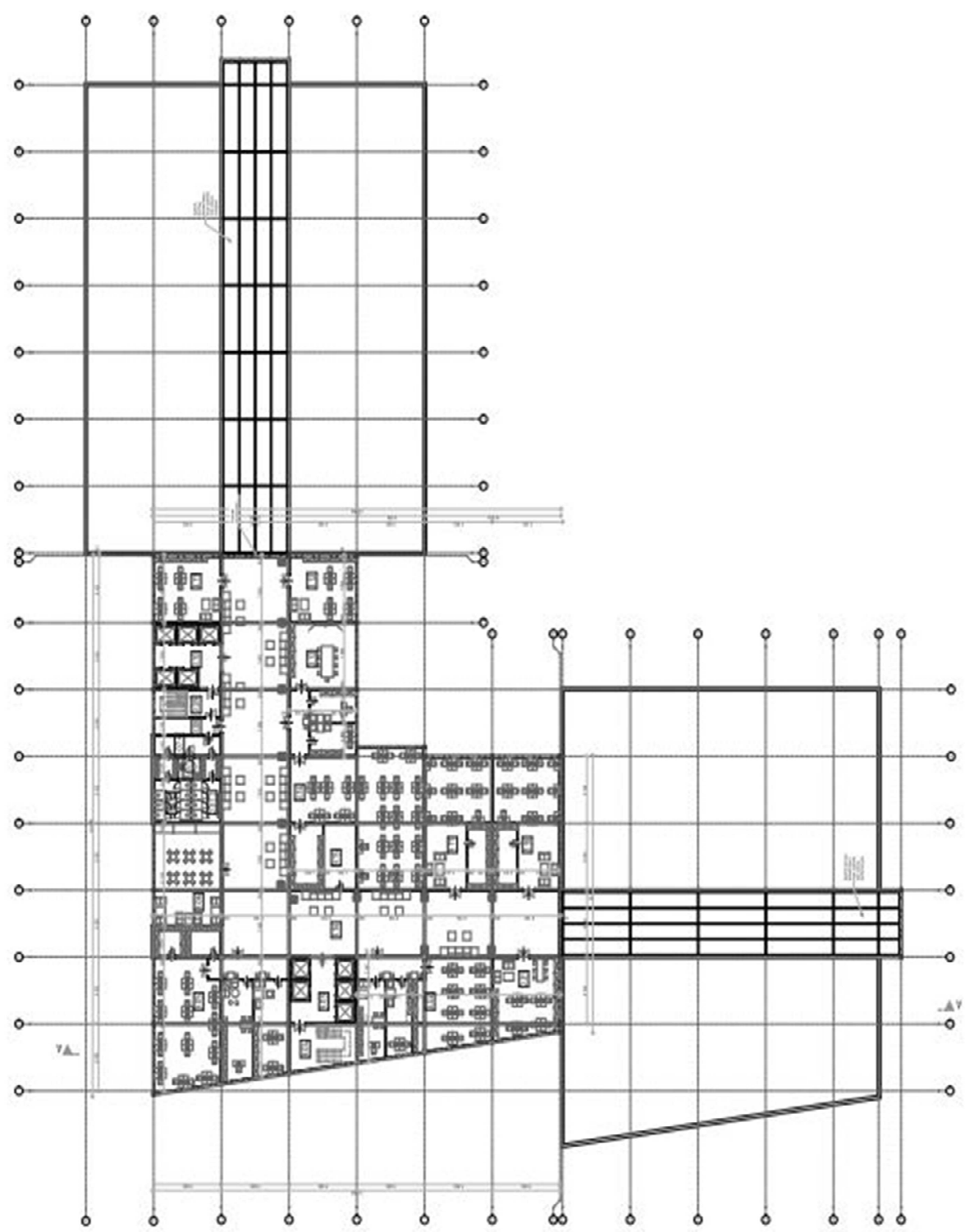

Rys. 12. Rzut III-VIII kondygnacji. Fragment pracy dyplomowej Marty Jańczuk - Projekt architektoniczny wysokiego budynku biurowego

Fig. 12. Floor plan view (third to eleven). Fragment of Marta Jańczuk diploma thesis - Architectonic project of the high office building

\subsection{Konstrukcja}

Budynek biurowy został zaprojektowany w konstrukcji szkieletowej żelbetowej, oparty jest na 12 traktach poprzecznych i 15 podłużnych. Główny element 
konstrukcji stanowią słupy o przekroju kwadratowym $30 \times 30 \mathrm{~cm}$, posadowione na stopach i ławach fundamentowych. Ich rozstaw osiowy oparty jest na siatce o wymiarach 9,00 m na 8,10 m. Do zbrojenia konstrukcji zastosowano stal klasy A- IIIN w związku z występującymi obciążeniami.

Elementem nośnym ścian są poprzeczne i podłużne podciągi oraz belki konstrukcyjne, o wysokości przekroju $35 \mathrm{~cm}$ do $50 \mathrm{~cm}$, na których oparte są stropy gęstożebrowe o rozpiętości 9,00 m na 8,10 m. Maksymalna wysokość kondygnacji w parterze 4,20 m. Część wysoka administracyjno-biurowa również o konstrukcji żelbetowej w układzie powtarzalnym o wysokości kondygnacji 3,20 m.

Część wysoka budynku posiada konstrukcję zewnętrzną, osłonową stanowią elementy elewacji systemowych. W części niskiej do 3 kondygnacji ściany zewnętrzne osłonowe wykonane z pustaków Porotherm 38 T DRYFIX. Elewacje niższych części zaprojektowane $\mathrm{z}$ eleganckich matowych płyt włókowo-cementowych, które cechują się możliwością barwienia w odcieniach szarości. Płyty montowane do elewacji na specjalnych kotwach.

Komunikacja pomiędzy kondygnacjami oparta o schody żelbetowe monolityczne, wylewanych na miejscu budowy. Komunikację pionową stanowią zamknięte klatki schodowe, spełniające warunki przeciwpożarowe, oraz halle windowe z dźwigami pionowymi (trzony budynku).

Przerwa dylatacyjna zaprojektowana została w dwóch miejscach. Dylatacje wprowadzono w miejscach gdzie wysokość budynku jest zróżnicowana.

Ostatnią kondygnacja budynku stanowi dach płaski o spadkach 3\%. Zaprojektowany dach to stropodach pełny o odwróconym układzie warstw. Maksymalna wysokość budynku wynosi 37,90 m.

\section{Podsumowanie}

Powstawanie zabudowy wysokiej w tkance miejskiej rozwijających się miast takich jak Rzeszów jest zjawiskiem naturalnym. Jest to istotny oraz pozytywny element rozwoju przestrzennego, jednakże należy pamiętać o zabudowie istniejącej. Miejskie śródmieścia zazwyczaj są ważne pod względem historycznym oraz kulturowym, więc powinno się ,podchodzić” do projektowania w ich obrębie z poszanowaniem zastanej zabudowy. Kształtowanie wysokich obiektów architektury w zabudowie miejskiej nie może spełniać samej potrzeby stworzenia wysokiego budynku, lecz czynić to w sposób wiarygodny, wpisujący obiekt w charakter danego miejsca w mieście. Architektura zrównoważona, przemyślana wpisuje się w genius loci danego miejsca, staje się elementem gry w miasto, doświadczaniem różnych kreacji przestrzeni. Zdecydowana, zintegrowana $\mathrm{z}$ otoczeniem architektura charakteryzować się będzie warstwą znaczeniową o cechach siłą rzeczy monumentalnych. Naturę obu przedstawionych budynków stanowią formy architektury mające odmienną wymowę graficzną i plastyczną, ale oba obiekty wnikają z przestrzeni danego obszaru miasta i wykorzystują jej chwilową dyspozycję przestrzenną. 
Powstanie dobrej architektury, to odpowiedź na poprawnie postawione pytania funkcjonalne, systemowe i percepcyjne. Formułowanie tych specyficznych pytań jest zróżnicowane i uzależnione od sytuacji lokalnej, musi uwzględniać wieloaspektowość: kulturową, społeczną, geograficzną, krajobrazową, ekonomiczną.

Żyjemy w społeczeństwie z wykształconym nawykiem mobilności w przestrzeni opartej o orientację w przestrzeni z wykorzystaniem akcentów wysokościowych w przestrzeni. Jesteśmy globalnymi odkrywcami, poszukujemy, penetrujemy nowe obszary, odnajdujemy siebie w skrajnie odległych miejscach. Architektura podąża tropem nas samych. Będzie odkrywać nowe możliwości kształtowania przestrzeni miejskiej. To podstawowa cech współczesnego innowacyjnego design miejskiego.

\section{Literatura}

[1] Pawłowski Z., Cała I.: Budynki wysokie, Wydawnictwo Politechniki Warszawskiej, Warszawa 2006.

[2] Skidmore, Owings \& Merrill: Architektura i architekci świata współczesnego, Wydawnictwo Arkady, Warszawa 1989.

[3] Wejchert K.: Elementy kompozycji urbanistycznej, Wydawnictwo Arkady, Warszawa 2008.

[4] Oficjalna strona internetowa Urzędu miasta Rzeszowa, www.rzeszow.pl/turystyka/ wizytowka-miasta (dostęp 15.03.2015).

\section{DEVELOPMENT OF HIGH OBJECTS OF ARCHITECTURE IN THE RZESZOW URBAN SPACE}

\section{S u m m a r y}

The issue of Formation of high architecture in the urban area is present in architecture, Urban planning and social science since start of XX century until contemporary. References to the idea are seen today in practice and theory of architecture in projects of the buildings and in publications. The article introduces the subject describing the idea of Formation of high architecture in the urban area - Its roots and cultural background. Two example of project of high rise buildings in Rzeszow were described. Attempt to answer the question of whether the development of high architecture in the urban area of Rzeszow is justified spatially. The appearance of the development of high architecture in the urban area of Rzeszow in two guises - as a response to the needs of the city. Moving the stability problem of structural and technological Shaping the shape of the object based on the selected design solutions, optimization of the solid solutions applied. Architecture depends on the place where the counterbalances the instability of repetitive solutions presented in two different locations of the urban environment Rzeszow.

Keywords: architecture of offices and hotels, forming lumps, durability, urban environment, Rzeszow

Przestano do redakcji: $2.10 .2016 r$.

Przyjęto do druku: 30.06.2017 r. 